\title{
Genome-wide characterization of folate transporter proteins
}

\section{of eukaryotic pathogens [version 1; peer review: 2 approved}

\section{with reservations]}

\author{
Mofolusho Falade (iD), Benson Otarigho (D1,2 \\ ${ }^{1}$ Cellular Parasitology Programme, Department of Zoology, University of Ibadan, Ibadan, Nigeria \\ ${ }^{2}$ Department of Biological Science, Edo University, Iyamho, Nigeria
}

\author{
V1 First published: 12 Jan 2017, 6:36 \\ https://doi.org/10.12688/f1000research.10561.1 \\ Latest published: $13 \mathrm{Jul} 2017,6: 36$ \\ https://doi.org/10.12688/f1000research.10561.2
}

\section{Abstract}

Background: Medically important pathogens are responsible for the death of millions every year. For many of these pathogens, there are limited options for therapy and resistance to commonly used drugs is fast emerging. The availability of genome sequences of many eukaryotic protozoa is providing important data for understanding parasite biology and identifying new drug and vaccine targets. The folate synthesis and salvage pathway are important for eukaryote pathogen survival and organismal biology and may present new targets for drug discovery.

Methods: We applied a combination of bioinformatics methods to examine the genomes of pathogens in the EupathDB for genes encoding homologues of proteins that mediate folate salvage in a bid to identify and assign putative functions. We also performed phylogenetic comparisons of identified proteins. .

Results: We identified 234 proteins to be involve in folate transport in 63 strains, 28 pathogen species and 12 phyla, $60 \%$ of which were identified for the first time. Many of the genomes examined contained genes encoding transporters such as folate-binding protein $\mathrm{YgfZ}$, folate/pteridine transporter, folate/biopterin transporter, reduced folate carrier family protein, folate/methotrexate transporter FT1. The mitochondrion is the predicted location of the majority of the proteins, with $15 \%$ possessing signal peptides. Phylogeny computation shows the similarity of the proteins identified.

Conclusion: These findings offer new possibilities for potential drug development targeting folate-salvage proteins in eukaryotic pathogens.

\section{Keywords}

Folate transporter, Eukaryotic pathogens, Drug discovery, Putative homologues

\section{Open Peer Review \\ Approval Status? ? 2 \\ version 2 \\ (revision)

$\begin{array}{cc}? & ? \\ \text { view } & \text { view } \\ ? & \\ \text { view } & ?\end{array}$ \\ 1. Raphael D. Isokpehi, Bethune-Cookman University, Daytona Beach, USA \\ 2. Gajinder Singh ID, International Centre for Genetic Engineering and \\ Biotechnology (ICGEB), New Delhi, India \\ Any reports and responses or comments on the article can be found at the end of the article.}




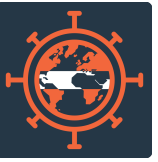

This article is included in the Neglected Tropical

Diseases collection.

Corresponding author: Mofolusho Falade (mo.falade@ui.edu.ng)

Competing interests: No competing interests were disclosed.

Grant information: B.O. was supported by a TWAS-CNPq fellowship (FP number: 3240274297)

The funders had no role in study design, data collection and analysis, decision to publish, or preparation of the manuscript.

Copyright: ( $\subset 2017$ Falade $\mathrm{M}$ and Otarigho B. This is an open access article distributed under the terms of the Creative Commons

Attribution License, which permits unrestricted use, distribution, and reproduction in any medium, provided the original work is properly cited. Data associated with the article are available under the terms of the Creative Commons Zero "No rights reserved" data waiver (CCO 1.0 Public domain dedication).

How to cite this article: Falade $\mathrm{M}$ and Otarigho $\mathrm{B}$. Genome-wide characterization of folate transporter proteins of eukaryotic pathogens [version 1; peer review: 2 approved with reservations] F1000Research 2017, 6:36

https://doi.org/10.12688/f1000research.10561.1

First published: 12 Jan 2017, 6:36 https://doi.org/10.12688/f1000research.10561.1 


\section{Introduction}

A heterogeneous diversity of eukaryotic pathogens is responsible for the most economically important diseases of humans and animals $^{1,2}$. As a result of underdevelopment, a lack of social infrastructure and insufficient funding of public health facilities, most of these pathogens are endemic to resource-poor countries in subSaharan Africa, South-East Asia and South America, where they are responsible for high morbidity and mortality ${ }^{1-3}$. Of these, parasitic protozoa form a major group, with the apicomplexans and kinetoplastid parasites represented by important members, which cause diseases such as malaria, cryptosporidiosis, toxoplasmosis, babesiosis, leishmaniasis, Human African trypanosomiasis and south American trypanosomiasis or Chagas' disease causing most of the morbidity and mortality ${ }^{4,5}$. Other important diseases caused by protozoans include giardiasis, amoebic dysentery ${ }^{6,7}$ and trichomoniasis ${ }^{8}$. A vicious cycle of poverty and disease exists for most of these parasites with a high infection and death rate in affected populations ${ }^{9-11}$. The appreciable burden of disease caused by these parasites has been aggravated by the lack of a licensed vaccine for most of them ${ }^{12}$. Furthermore, current drugs of choice for treatment for many of the parasites have significant side effects, with the added emergence of drug resistant strains ${ }^{13-15}$. Despite the urgent demand for new therapies for control, few drugs have been developed to combat these parasites ${ }^{16}$. A major limitation to the development of new drugs is the paucity of new drug targets. There is therefore a need for discovery of novel and alternate potential chemotherapeutic targets that can help in drug development efforts for disease control ${ }^{16-18}$. A possible approach to selective antimicrobial chemotherapy has been to exploit the inhibition of unique targets, vital to the pathogen and absent in mammals ${ }^{17,18}$.

A metabolic pathway that has been exploited considerably for the development of drugs is the folate biosynthetic pathway ${ }^{19}$. Antifolate drugs target this pathway and are the most important and successful antimicrobial chemotherapies targeting a range of bacterial and eukaryotic pathogens. While most parasitic protozoa can synthesize folates from simple precursors, such as GTP, p-aminobenzoic acid (pABA) and glutamate, higher animals and humans cannot ${ }^{20}$. Additionally, a few of these parasites can also salvage folate as nutrient from their host ${ }^{21}$. These folate compounds are important for synthesis of DNA, RNA and membrane lipids and are transported via receptor-mediated or/and carrier-mediated transmembrane proteins; folate transporters ${ }^{20-22}$. Importantly, antifolate chemotherapies that target the biosynthesis and processing of folate cofactors have been effective in the chemotherapy of bacterial and protozoan parasites ${ }^{21}$. More importantly, the folate pathway has also been confirmed as being essential in some eukaryotic pathogens such as Plasmodium, trypanosomes and Leishmania ${ }^{19}$.

In addition to the folate biosynthesis pathway, proteins that mediate transport of useful nutrients such as folic acid have been identified as important chemotherapeutic drug targets ${ }^{18,19,23}$. Hence, the folate pathway, metabolites and transporters continue to be extensively studied for identification of new enzymes including transporters, which may serve as new drug targets ${ }^{22}$. Recent estimates have ascribed eight different membrane transporters to eukaryotes ${ }^{24}$.
Proteins that mediate transportation of folates have been well studied in a few parasites such as Plasmodium falciparum, Trypanosoma brucei, Leishmania donovani and Leishmania major ${ }^{25,26}$. These studies have provided information on mode of action of drugs $s^{25,27,28}$ in addition to studies describing mechanisms of parasite drug resistance ${ }^{25-32}$. However, folate transport proteins remain unidentified and uncharacterized in many other eukaryotic pathogens. This is despite the sequencing of the genomes of most eukaryotic pathogens, which has produced a vast wealth of data that could aid in identification of druggable pathogen-specific proteins ${ }^{33-39}$. It is therefore imperative to search and identify from these parasite genomes additional proteins such as folate transporters that may serve as novel drug targets ${ }^{40,41}$.

Therefore, in an attempt to identify and characterize targets for novel therapeutics, we report herein an extensive search of folate transporters from pathogen genomes. In addition, we investigated the evolutionary relationship of these transporters in a bid to determine similarities and differences that make them attractive drug targets. The knowledge provided may assist in the design of new antifolates for protozoan parasites.

\section{Methods}

Our experiment workflow is depicted in Figure 1. We extracted protein sequences of approximately 200 pathogens that mediate transportation or salvage of folates from Eukaryotic Pathogen Genome Database Resources (http://eupathdb.org/eupathdb/), and from the literature using a key-word search. We also searched the 200 pathogen genome sequences archived at the Eukaryotic Pathogen Genome Database Resources (http://eupathdb.org/eupathdb/). The search was for all proteins that mediate transportation or folate salvage alone or folate salvage and related compounds (such as pteridine, biopterin and methotrexate) together. This database gives public access to most sequenced emerging/re-emerging infectious pathogen genomes ${ }^{42}$. We utilized the word "folate" for search on the gene text and "folic acid" was used to confirm the hits. Hit results containing proteins annotated as folate-binding protein YgfZ, folate/ pteridine transporter, folate/biopterin transporter, reduced folate carrier family protein, folate/methotrexate transporter FT1, Folate transporters alone and other folate related proteins were retrieved. The complete list of proteins extracted from Eupthadb is presented in Dataset $1^{43}$. The folate transporters were classified based on type of transporter, number of transmembrane helix (TMH) and localization (either cell or mitochondrial membrane) of transporter. Gene sequences were obtained in FASTA format for transporter proteins using the sequence download tool on EupathDB (http://eupathdb. org/eupathdb/).

To ensure that most of the retrieved proteins had not been previously studied, we performed a literature search on PubMed (http:// www.ncbi.nlm.nih.gov/pubmed/?term=) and Google Scholar (https://scholar.google.com) using the query "folate transporter + Parasite name". The protein sequence information (Dataset $1^{43}$ and Table 1) obtained from literature search was used for a BLAST search on EupathDB (http://eupathdb.org/eupathdb/), UniprotDB (http://www.uniprot.org) and GeneDB (http://www.genedb.org/ Homepage). Sequence data were edited on textEdit mac version 


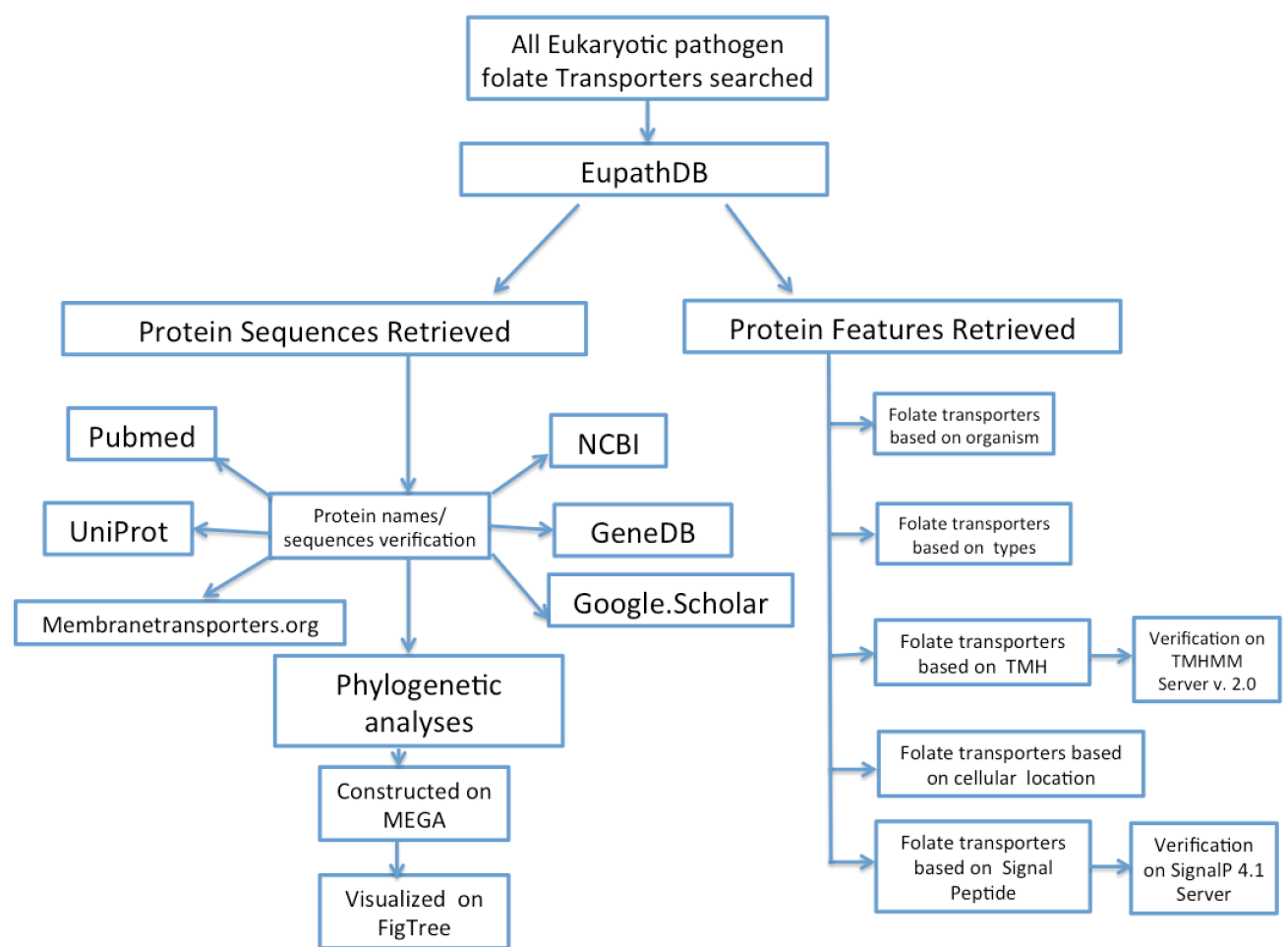

Figure 1. Conceptual hierarchical methodology workflow showing the various steps employed in this study to identify, characterize and curate protozoan folate transporters.

and uploaded to Molecular Evolutionary Genetics Analysis (MEGA) platform version 7.0 obtained from http://www.megasoftware.net $t^{44}$. The 234 sequences were aligned using muscle tools with large alignment (Max iterations = 2) selected while other settings were left at defaults. Evolutionary history was inferred using the Neighbor-Joining method ${ }^{45}$. The percentage of replicate trees in which the associated taxa clustered together in the bootstrap test (500 replicates) was also analysed ${ }^{46}$. The tree was drawn to scale, with branch lengths in the same units as those of the evolutionary distances used to infer the phylogenetic tree. The evolutionary distances were computed using the number of differences method ${ }^{47}$. While uniform rate and complete deletion was selected for substitution rates and data subset, respectively. Other parameters were at default settings. All positions containing gaps and missing data were eliminated. The newick format of the tree was exported and opened on FigTree 1.4.2 platform downloaded from http://ree.bio.ed.ac. uk/software/figtree/ ${ }^{48}$. The final tree was constructed using radial tree layout. Additional analysis consisted of sub-phylogenies based on the transporter type. Since folate-binding protein YgfZ, folate/ pteridine transporter, folate/biopterin transporter, putative, reduced folate carrier family protein, folate/methotrexate transporter FT1, putative folate transporters alone and others have 10, 25, 132, 2, 7, 49 and 9. So we decided to reconstruct the phylogeny based folate transporter, folate-biopterin transporter after considering the identification number, the species diversity in each category.

\section{Results}

A methodological search for folate transporters in all eukaryotic pathogen genomes we examined under EupathDB with validation via GenBank, GeneDB and Uniprot contained a total of 234 proteins (detail features of proteins are presented in Dataset $1^{43}$ ). We identified these transporters in 28 pathogen species (containing 63 strains) cutting across 12 phyla (Table 1). The parasites with the highest number of folate transporters are Phytophthora parasitica INRA-310, P. infestans T30-4 and Leptomonas pyrrhocoris H10 with 20, 16 and 16 proteins, respectively. While Aspergillus clavatus NRRL 1, A. flavus NRRL3357, A. macrogynus ATCC 38327, Crithidia fasciculata strain $\mathrm{Cf}-\mathrm{Cl}$ and others have one folate transporter protein each (Table 1). The different proteins identified to be involved in folate salvage or related molecules were folatebinding protein $\mathrm{YgfZ}$, folate/pteridine transporter, folate/biopterin transporter, reduced folate carrier family protein, folate/methotrexate transporter FT1 and folate transporters having a $4 \%, 11 \%$, $56 \%, 1 \%, 3 \%$ and $21 \%$ identity, respectively. Proteins that did not belong to these groups were classified as others (4\%) (Figure 2A). A good number of the proteins identified had predicted transmembrane helixes with a few having none (Figure 2B). Furthermore, a number of the transporters possess signal peptides (Dataset $1^{43}$ ), which may be required for targeting to cellular locations. Deciphering the sequence of the targeting signal may indicate its product destination. 


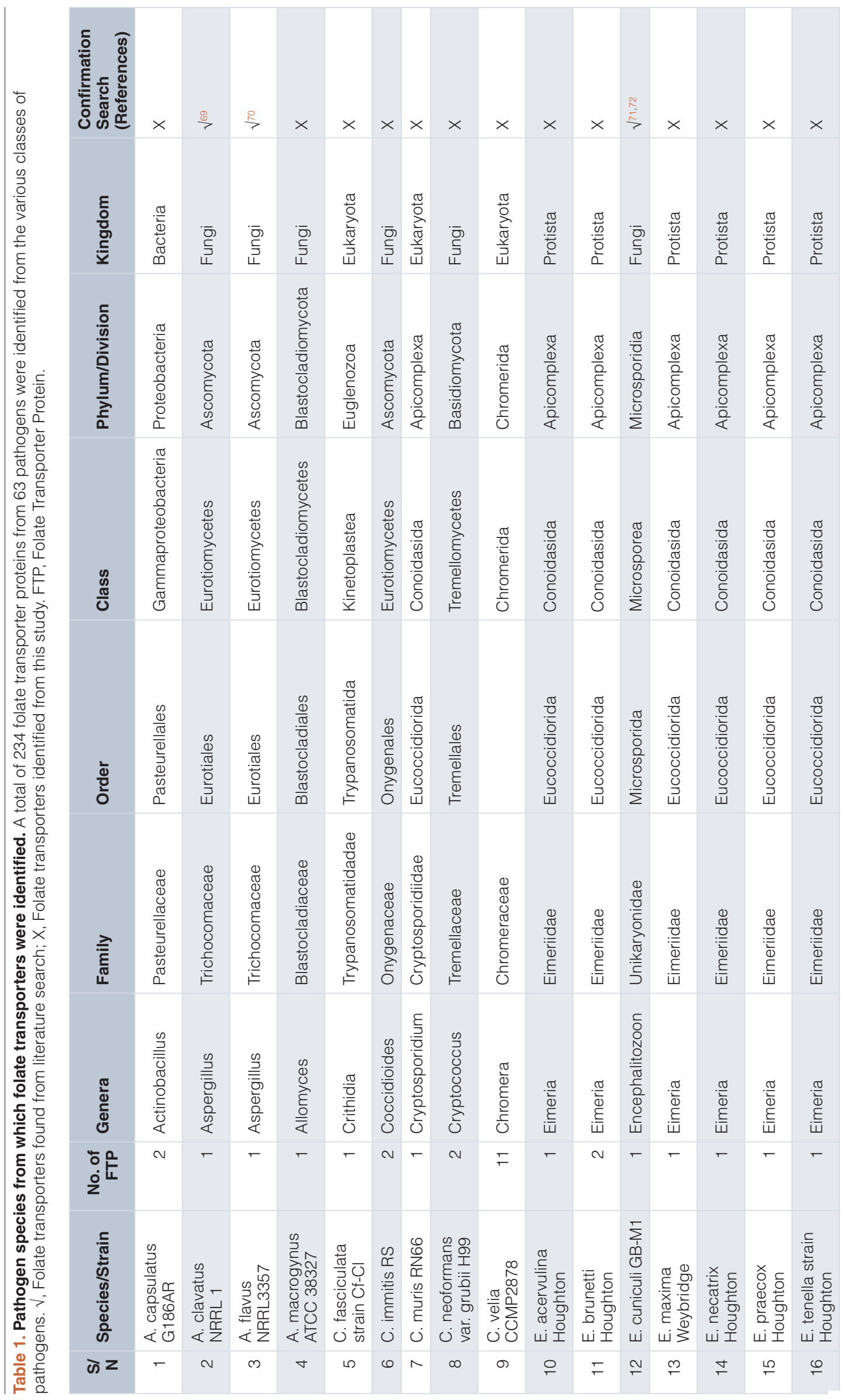




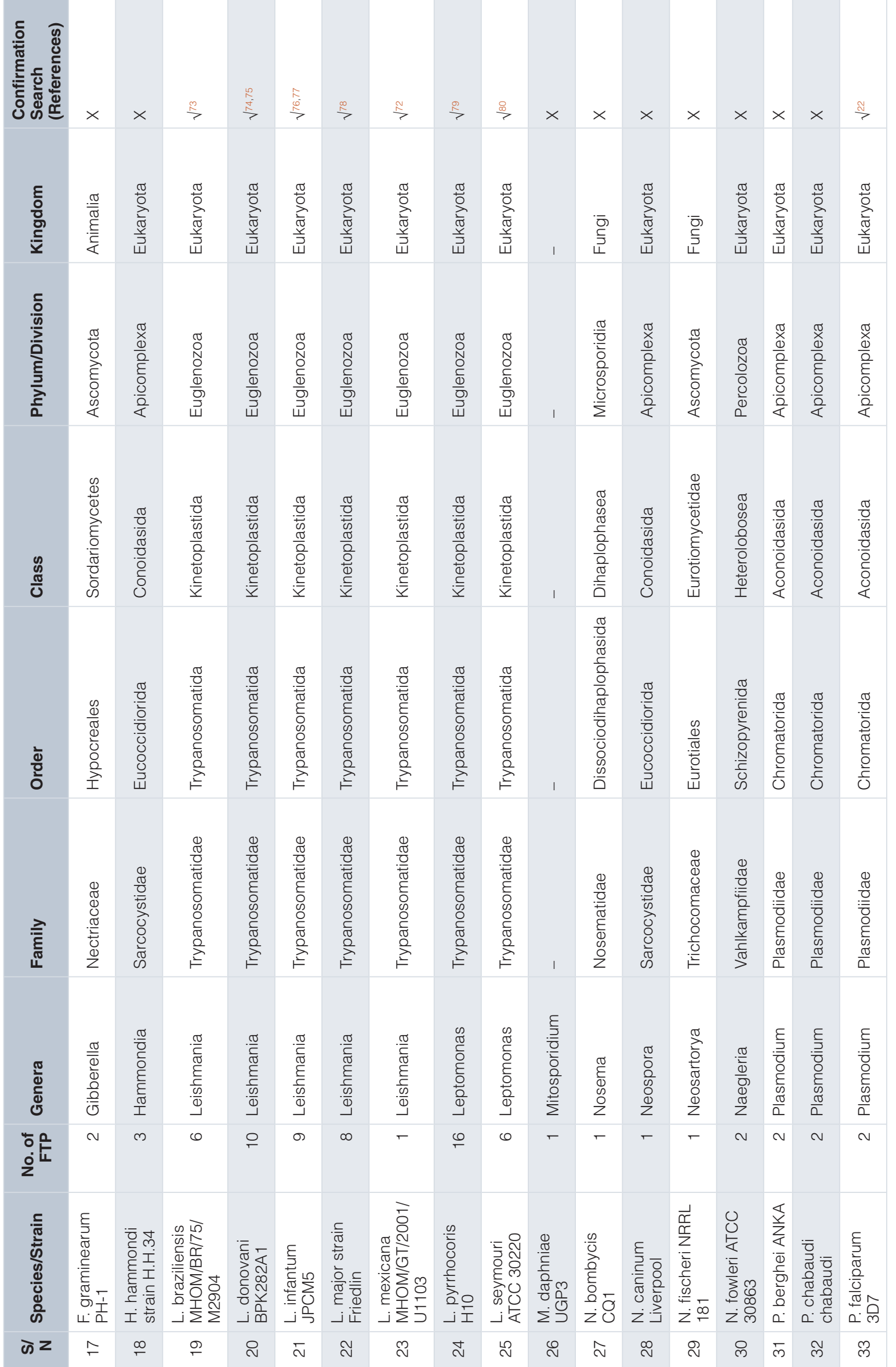




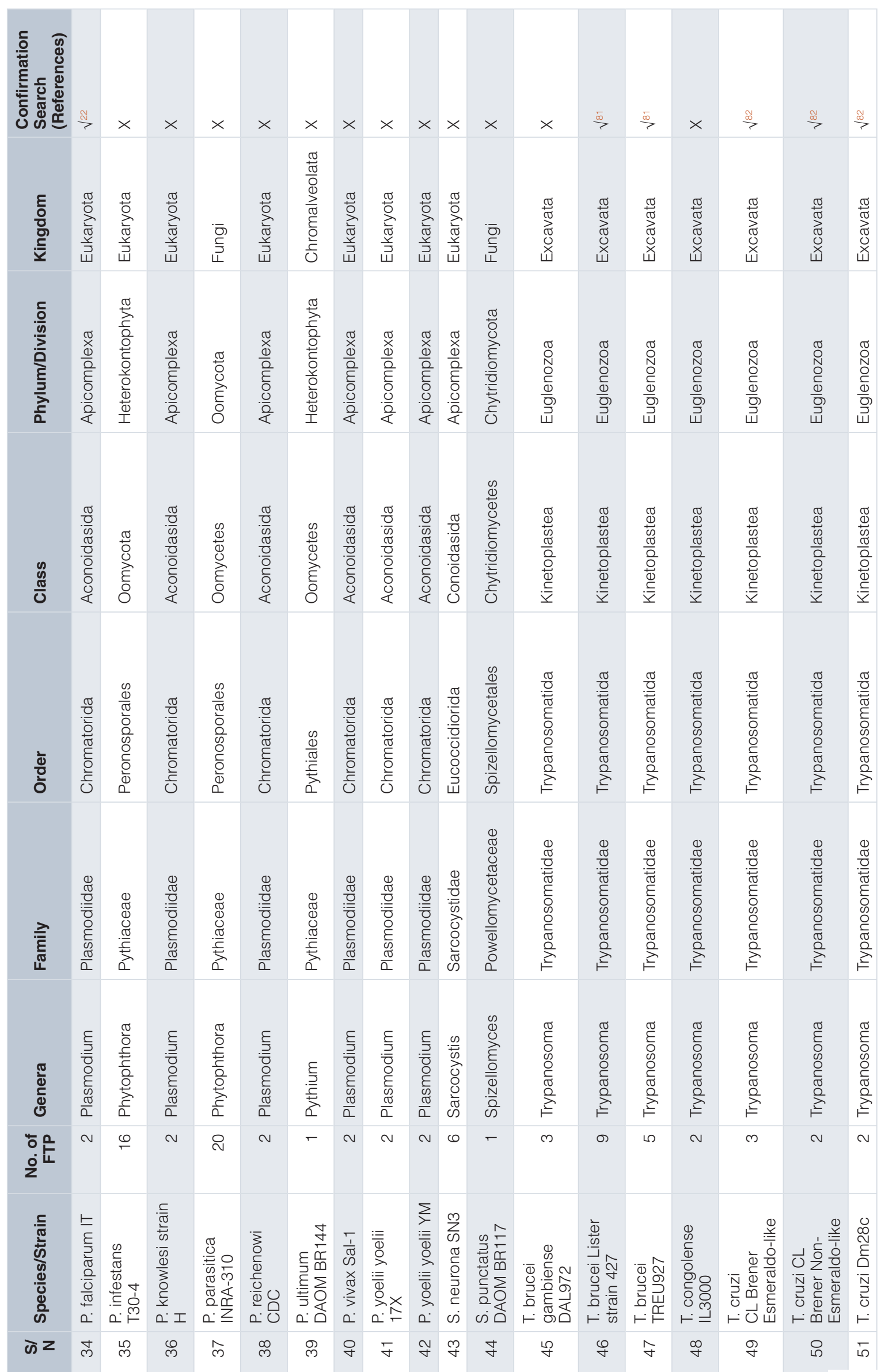




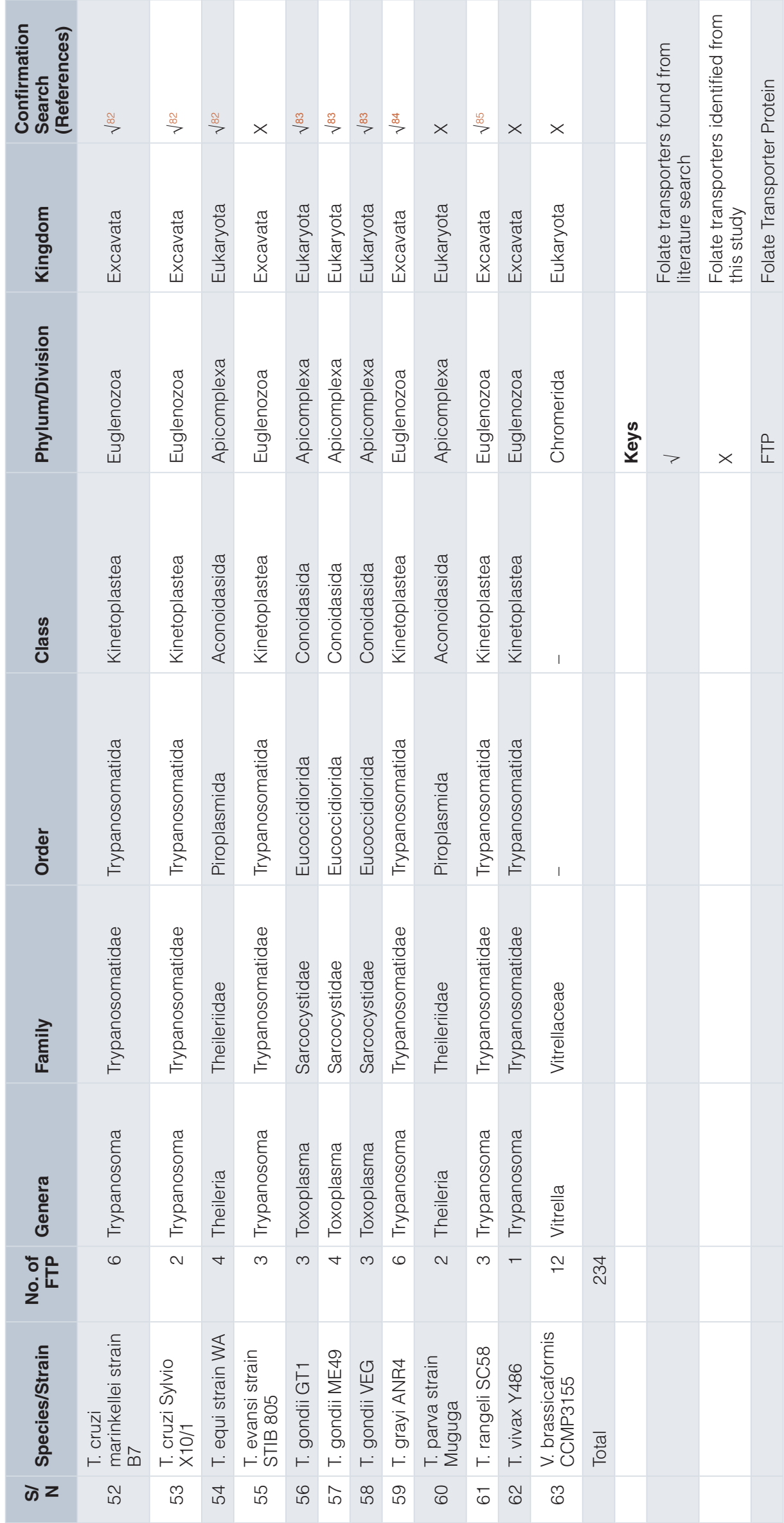


Our literature search for parasite folate transporters on PubMed and Google Scholar indicated 60\% (38 out 63) of the proteins were identified for the first time as presented in Table 1 and Figure $2 \mathrm{C}$, while $40 \%$ have been previously investigated. Besides, the Leishmania folate transporters we came across were not found on the EupathDB resource. We thus performed a BLAST search of Kinetoplastida on EupathDB, the returned hits were folate/biopterin transporter for $L$. infantum. The only Plasmodium species with results for proteins that salvage folate was $P$. falciparum. Our study, however, describes for the first time the presence of these transporters in other Plasmodium species. There were no transporter proteins deposited in EupathDB for P. malariae and P. ovale. However, folate transporters I and II were retrieved from our search of GeneDB for $P$. malariae and $P$. ovale curtisi, respectively.
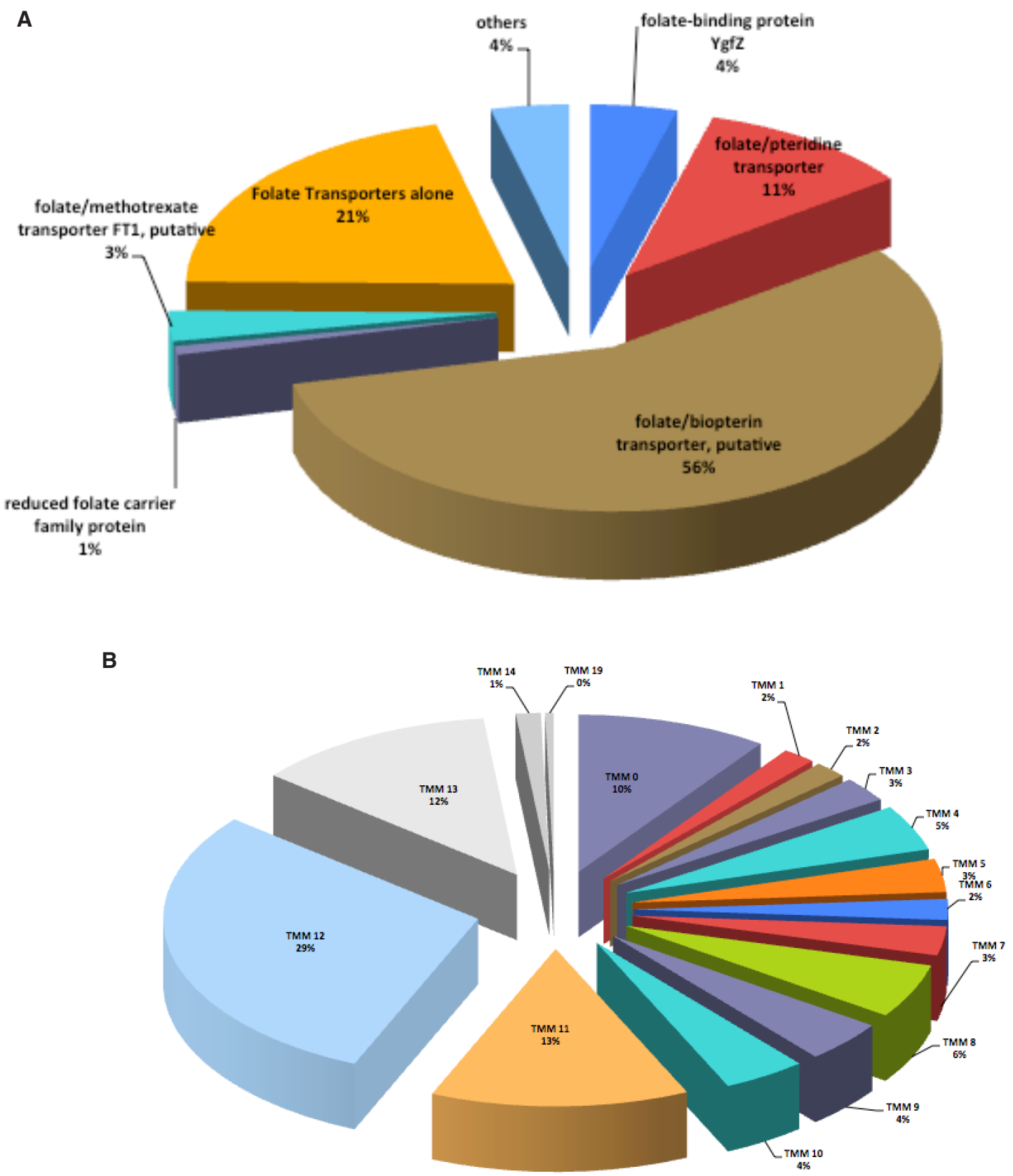
C

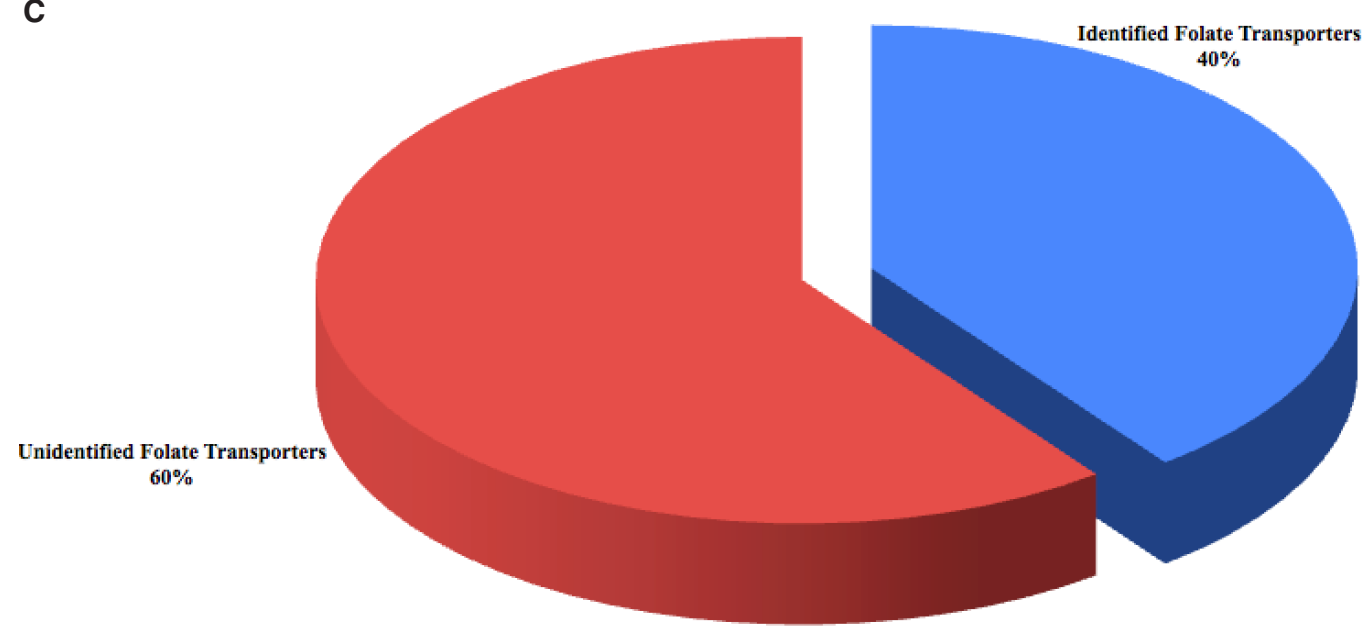

D

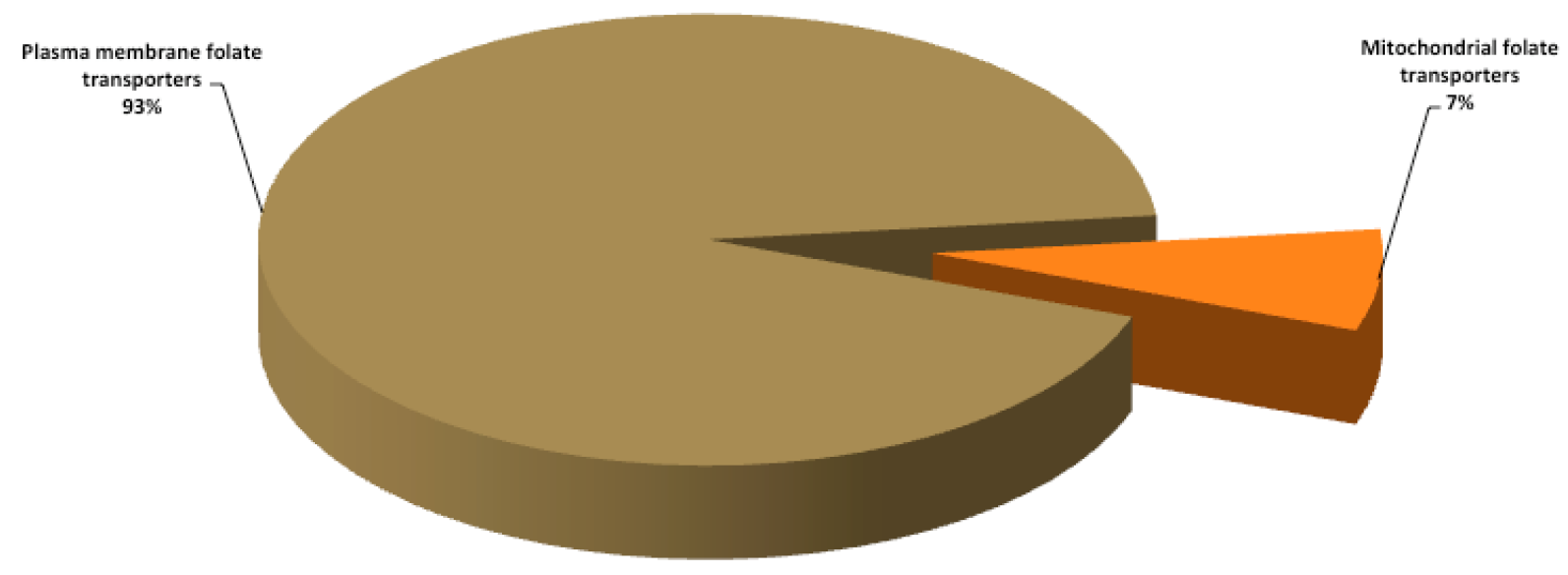

E

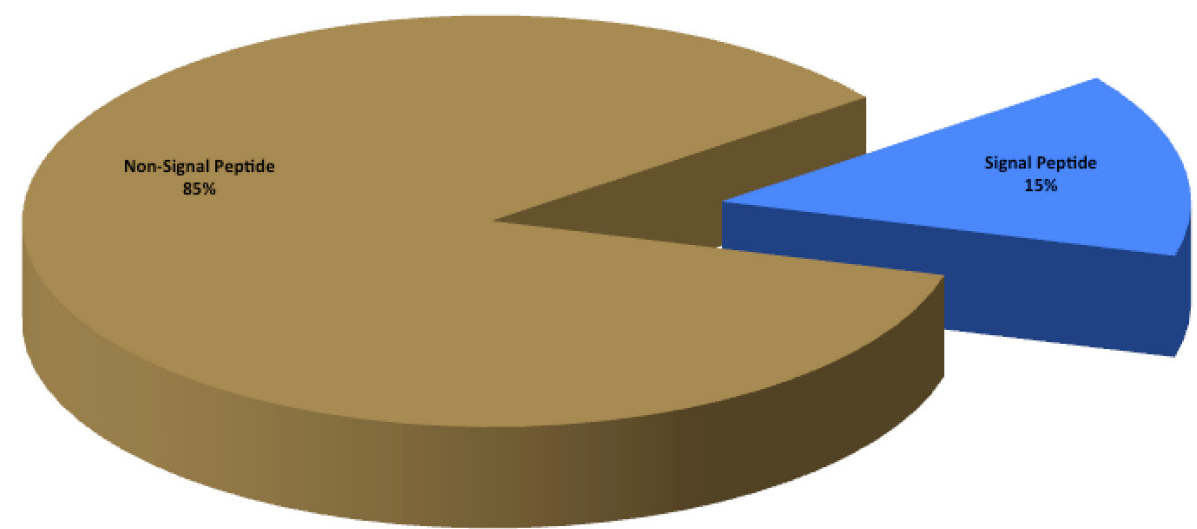

Figure 2. Categorization of proteins identified. This is based on $[\mathbf{A}]$ Transporter Type [B] Number of TMMs [C] Novel folate transporters [D] Localization [E] Presence/absence of Signal peptide. TMM, Transmembrane Helix; 
Our analysis of folate transporters indicate the presence in Plasmodium species of two proteoforms; folate transporter I and II (Dataset $1^{43}$ ). All Leishmania species identified possess folate/biopterin transporters and not folate transporters. Trypanosome species have both folate/pteridine and folate transporters; T. cruzi Dm28c, T. cruzi Sylvio X10/1 and T. cruzi CL Brener Esmeraldo-like, T. cruzi CL Brener Non-Esmeraldo-like and T. cruzi marinkellei strain B7 all have folate/pteridine transporter while $T$. brucei TREU927, T. brucei Lister strain 427, T. brucei gambiense DAL972, T. congolense IL3000 possess folate transporters. Eukaryotic parasites like Eimeria acervulina Houghton, E. brunetti Houghton, E. maxima Weybridge, E. necatrix Houghton, E. praecox Houghton, E. tenella strain Houghton and Neospora caninum Liverpool all boast folate/methotrexate transporter FT1. The folate-binding protein YgfZ was found in the fungus, Allomyces macrogynus ATCC 38327, the protist $C$. fasciculata strain $\mathrm{Cf}-\mathrm{Cl}$, C. immitis $\mathrm{RS}$, the feline protozoon, Hammondia hammondi strain H.H.34, Sarcocystis neurona SN3, S. punctatus DAOM BR117, T. gondii GT1, T. gondii ME49, T. gondii VEG and T. brucei TREU927. Parasites such as Microsporidium daphniae UGP3 and the amoeba Naegleria fowleri ATCC 30863 possess the reduced folate carrier family protein (Figure 2D). We observed that $7 \%$ of the identified proteins are localized on the mitochondrial membrane of some pathogens such as the fungi Aspergillus clavatus NRRL 1, A. flavus NRRL3357, C. immitis RS, the yeast Cryptococcus neoformans var. grubii H99, Fusarium graminearum PH-1, A. capsulatus G186AR, Leptomonas pyrrhocoris $\mathrm{H} 10$, the food fungus Neosartorya fischeri NRRL 181, Phytophthora parasitica INRA-310 and P. ultimum DAOM BR144. The remaining proteins are localized on the plasma membrane (Dataset $1^{43}$ and Figure 2D).

Approximately $15 \%$ (34/234) of the folate transporters identified possess signal peptides (Figure 2E) with the trypanosomes with the most signal peptides. Deductions can be made of the probable destination within the cell of any transporter by its signal peptide sequence; thus, further work may seek to decipher the sequence of the targeting signal to determine its localization. The proteins identified all have transmembrane helixes with the exception of the alveolate Chromera velia CCMP2878, apicomplexan P. berghei ANKA, S. neurona SN3, the kinetoplastid T. brucei TREU927, T. grayi ANR4 and protist Vitrella brassicaformis CCMP3155 with Gene ID's Cvel_17766, PBANKA_0713700, SN3_01500005, Tb927.8.6480, Tgr.2739.1000 and Vbra_15327, respectively (Dataset $1^{43}$ ).

The phylogenetic tree (Figure 3) shows the evolutionary position, history and relationship of all the folate transporters identified in this work. The type of transporter or species/strain was used for constructing phylogenic trees, with the 234 proteins identified forming two clades, a major and minor. The major clade lacked a sub-clade, while the minor clade possessed a sub-clade. All proteins identified were distributed between the two major clades; except for folate/methotrexate transporter and mitochondrial folate transporter, with the latter present on the major clade and the former on the minor clade exclusively. All the species are represented on both clades, however, V. brassicaformis CCMP3155, Plasmodium species, A. clavatus NRRL, A. flavus NRRL3357, A. macrogynus ATCC 38327, C. fasciculata strain Cf-Cl, C. immitis RS, C. immitis
RS, C. muris RN66, C. neoformans var. grubii H99, C. neoformans var. grubii $\mathrm{H} 99$, Leishmania species, $N$. bombycis CQ1, $N$. caninum Liverpool, F. graminearum PH-1 and H. hammondi strain H.H.34 are exclusively on the major clade. There are some parasites that were identified once, as shown in Dataset $1^{43}$; these are mostly in the large clade. Some of these pathogens include P. ultimum DAOM BR144, which has mitochondrial folate transporter/carrier proteins similar to Homo sapiens, E. cuniculi GB-M1, which has proteins similar to folate transporter, and S. punctatus DAOM BR117, which has folate-binding protein $\mathrm{YgfZ}$. These were the only proteins of the aforementioned species identified in this work. However, M. daphniae UGP3, which had reduced folate carrier domain containing protein, was the only parasite that was found in the small clade. Improving on our phylogenetic analysis, we performed a sub-phylogenetic reconstruction (Figure 4-Figure 6) based on the substrate type of the transport proteins. After phylogenetic analysis each sub-phylogeny show a clear characterization except for folate-biopterin transporters (Figure 5), which fell in a different clade save for Leptomonas species and C. velia.

Dataset 1. Complete list of proteins extracted from Eupthadb and literature search, including their properties

http://dx.doi.org/10.5256/f1000research.10561.d148742

These data are available in a .xlsx file.

\section{Discussion}

Folate transporters are important proteins involved in the salvage of folate, cofactors and related molecules in eukaryotic pathogens important for metabolism and survival in their respective hosts ${ }^{21}$. We identified proteins that could mediate the salvage of folates into cells and/or mitochondria from eukaryotic pathogen genomes in EupathDB. Many of these proteins are involved in folate biosynthesis or transport and are present in many of the eukaryotic pathogens we queried. In this study, 234 genes encoding homologues of folate salvaging proteins were identified in the genome of 64 strains, representing 28 species of eukaryotic pathogens. Some of the pathogens include P. falciparum 3D7 and IT, $P$. knowlesi $\mathrm{H}$, P. berghei ANKA, P. chabaudi chabaudi, T. brucei Lister 427, T. brucei TREU927, T. brucei gambiense DAL972, Encephalitozoon cuniculi GB-M1. The pathogens range from bacteria through to fungi, intracellular parasites such as Plasmodium and leishmania species, to extracellular parasites such as trypanosome species. This suggests a widespread presence of the proteins cutting across a range of pathogens that infect humans and animals.

A few of the proteins we identified have been previously identified and characterized in parasites such as Plasmodium falciparum ${ }^{22,30}$, Trypanosome species ${ }^{26}$, Leishmania species and Toxoplasma gondii $^{49}$. It has been estimated that over half of the drugs currently on the market target integral membrane proteins of which membrane transporters are a part, but unfortunately, these transporters have not been adequately explored as drug targets ${ }^{50}$. Folate transporters therefore represent attractive drug targets for treatment of infectious diseases. Thus their identification from other eukaryotic pathogens could open a window for novel chemotherapeutics for disease control $^{51,52}$. 


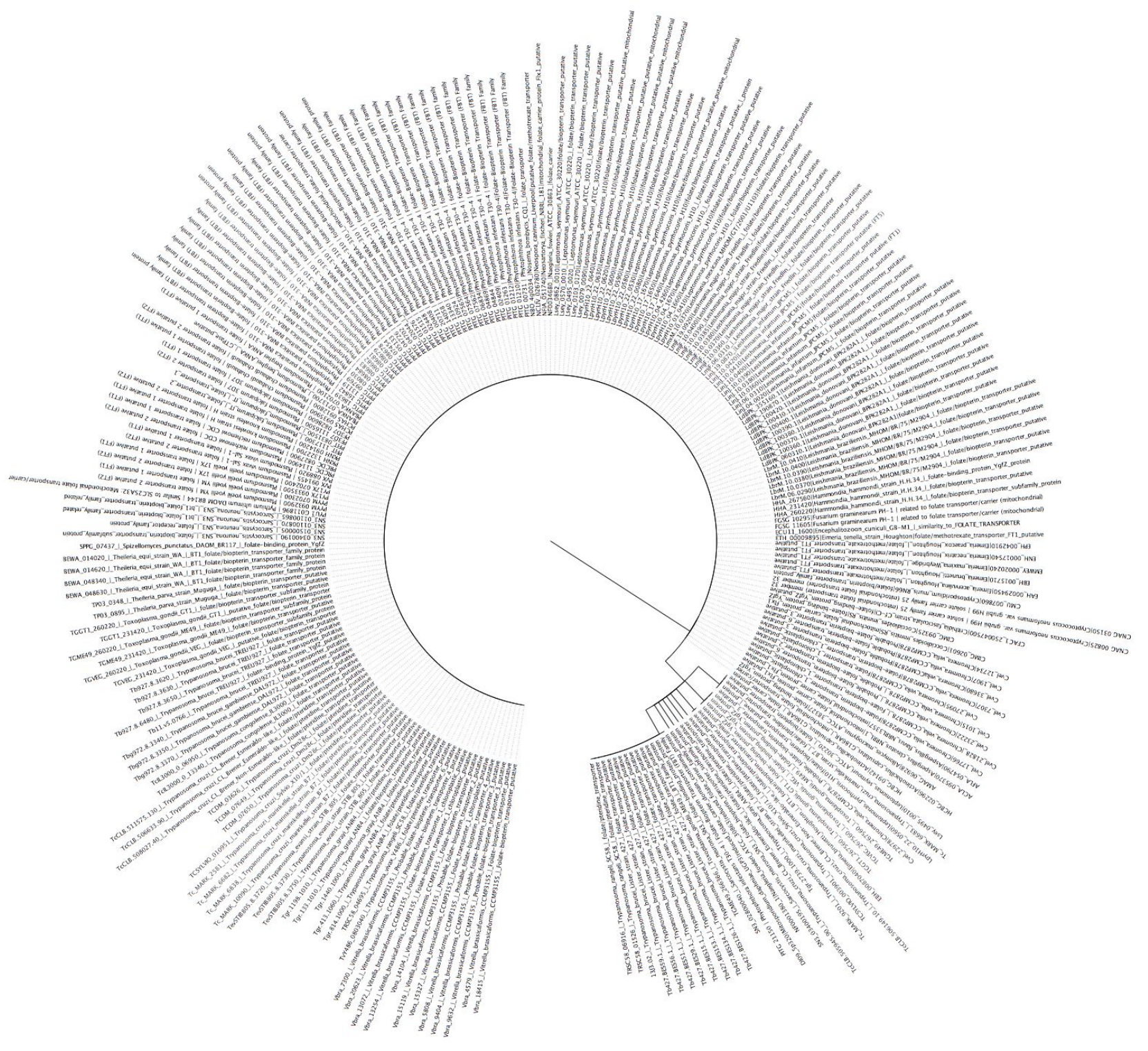




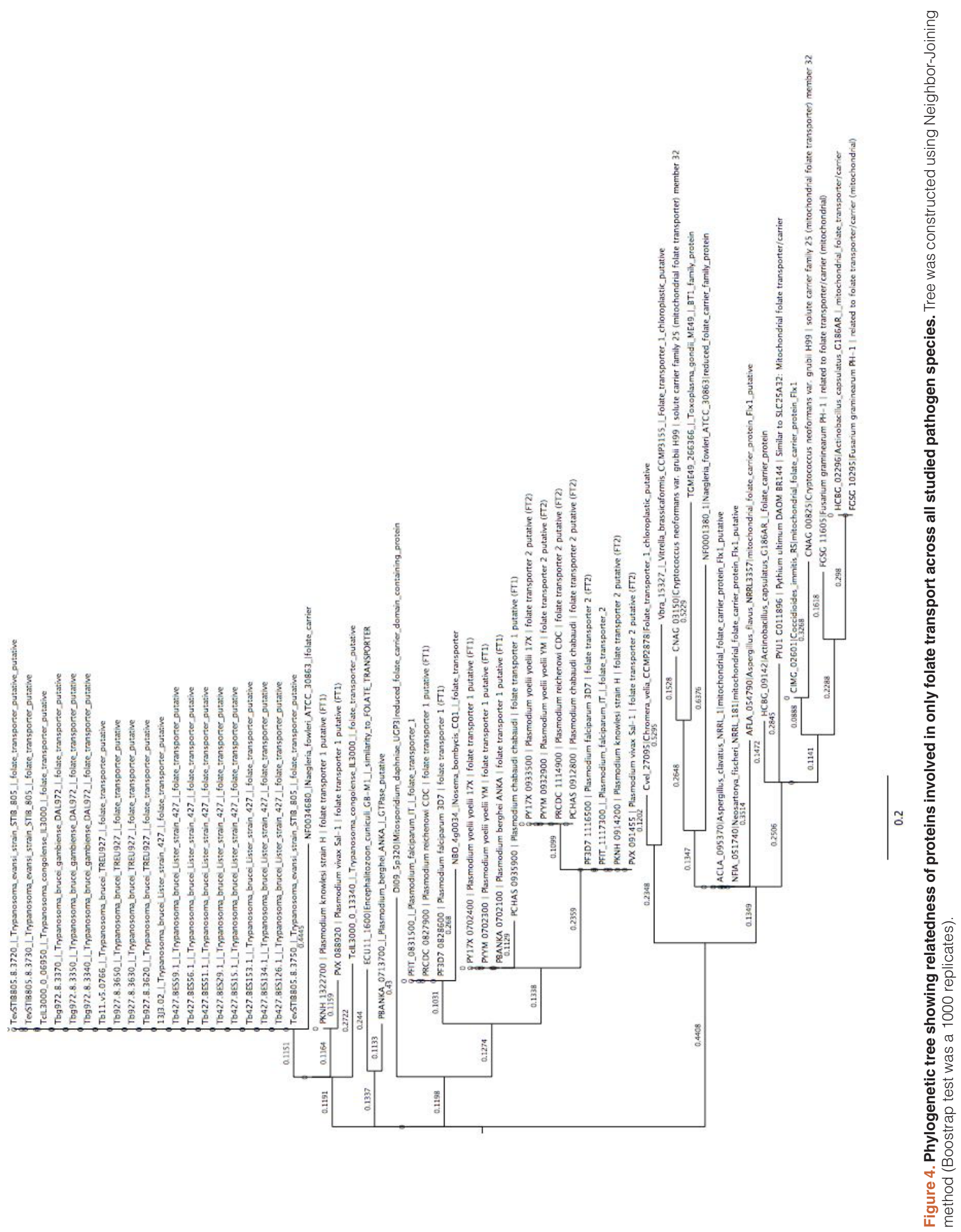




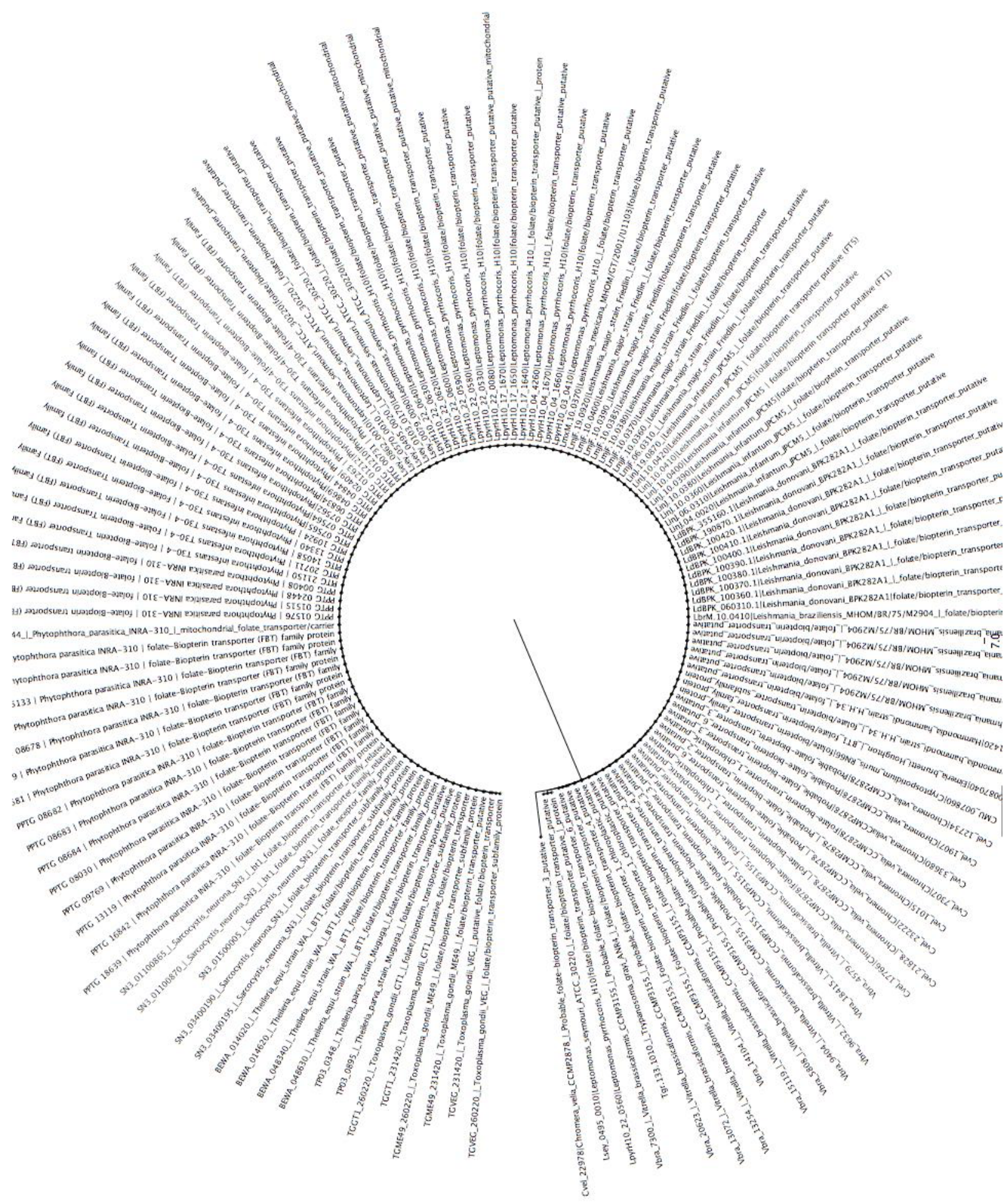




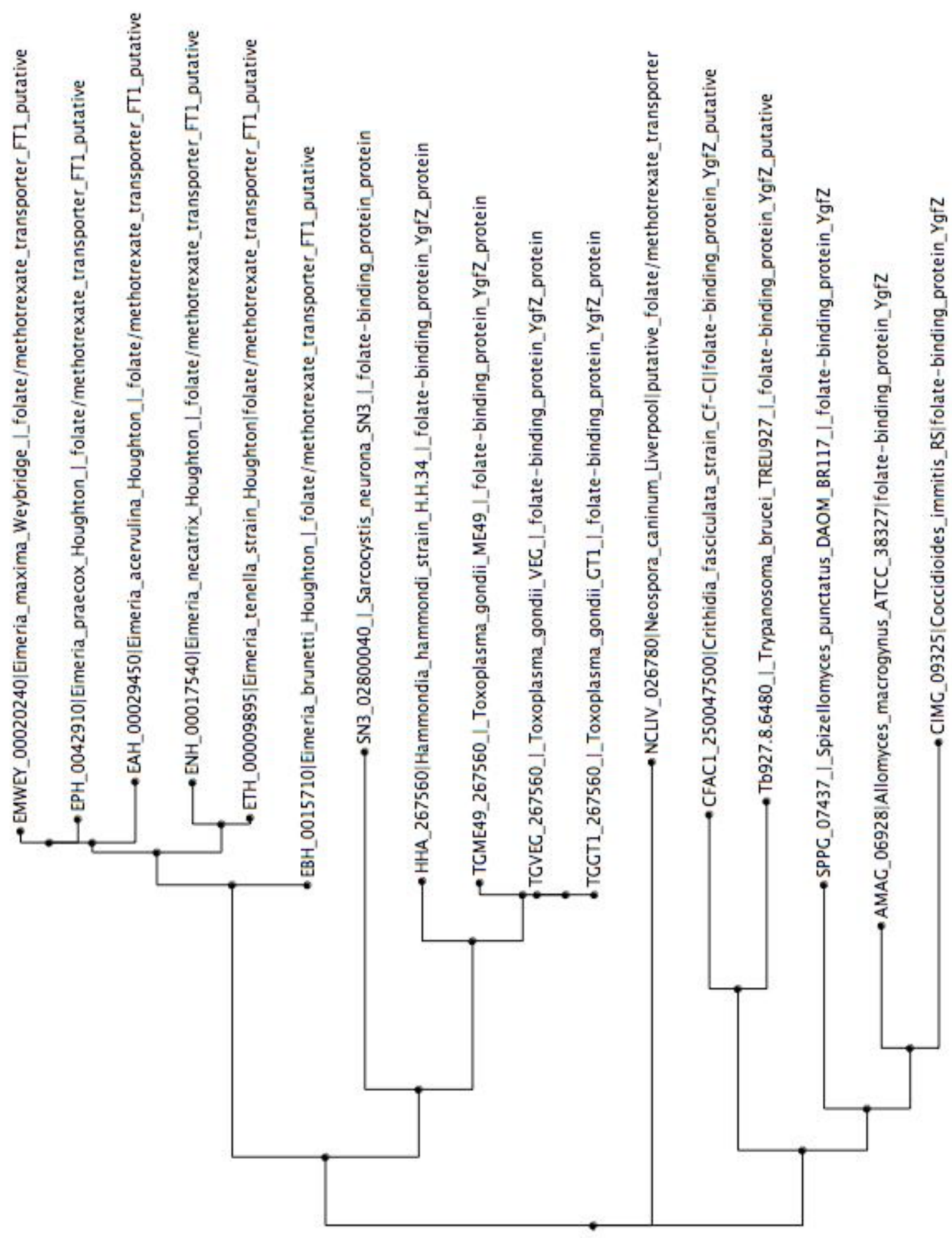


In Plasmodium two folate transporters have been identified, namely PfFT1 and PfT2. These transporters have been shown to mediate the salvage of folate derivatives and precursors in $P$. falciparum and proposed blocking of their salvage activities may improve the antimalarial efficacy of several classes of antimalarial drugs. In our work we identified folate transporters for other plasmodial species, which, like $P$. falciparum, may also be chemotherapeutic targets. Transport of folate in higher eukaryotes is made possible by a high affinity folate-biopterin transporters FBT or BT1 family ${ }^{22,30}$. In the trypanosomes and related kinetoplastids, a member of these transporters, the folate biopterin transporter (FBT) family of proteins was identified in Leishmania ${ }^{28}$. It is thought that MFS proteins are related to the FBT. These proteins have been characterized in a few protozoa and cyanobacteria ${ }^{53}$. Results from our study describing the presence of these transporters across several phyla corroborate results other researches, establishing the conservation of folate transport function among FBT family proteins from species from plants and protists ${ }^{22,53}$.

Malaria parasites encode transporters belonging to the organo anion transporter (OAT) folate-biopterin transporter (FBT), glycosidepentoside-hexuronide: cation symporter (GPH), families, which are closely related to the major facilitator super-family of membrane proteins ${ }^{54}$. The inhibition of these transporters by blockers of organic anion transporters such as probenecid has been implicated in sensitization of Plasmodium resistant parasites to antifolates ${ }^{55,56}$. Thus, in Plasmodium chemotherapy, identification of folate transporters could lead to screening for compounds that interfere with folate transport and salvage for antimalarial chemotherapy ${ }^{22,30}$. We identified several types of folate transporters that have been described and functionally characterized in Leishmania with some implicated in the import of the antifolate methotrexate ${ }^{57,58}$. Thus far, only protozoan transporters in Plasmodium, Leishmania, and Trypanosoma brucei have been characterized and these are known to mediate the uptake of the vitamins folate and/or biopterin ${ }^{22,59,60}$. Thus in parasites species of medical importance folate transporter proteins may provide new targets for therapy.

We also identified folate salvaging proteins from fungi such as Coccidioides immitis and A. clavatus, fungi found in soil ${ }^{61-63}$, vegetable $^{61}$ and waters in tropical and subtropical areas ${ }^{64}$. These fungi are known to occasionally become pathogenic and act as opportunistic pathogens for animals and $\operatorname{man}^{63}$. Coccidioidomycosis caused by $C$. immitis in association with AIDS has been known to be a fatal disease ${ }^{65}$. Treatment of acute and chronic infections with antifungals such as amphotericin B have not been adequate, hence folate transporters may present new targets in these group of pathogens. Identification was also made on pathogens such as C. fasciculata that parasitize several species of insects including mosquitoes and has been widely used to test new therapeutic strategies against parasitic infections ${ }^{66}$. As a model organism, folate transporters identified in $C$. fasciculata may be useful in research for developing new drugs in medically important Kinetoplasts as has been shown for other targets in this protozoan parasite ${ }^{67}$.

We noticed that $P$. parasitica INRA-310 and L. pyrrhocoris $\mathrm{H} 10$ had the highest number of folate transporters identified. Their utility as model fungal ( $P$. parasitica) and monoxenous kinetoplast may provide models instrumental for developing new antifolates for fungal and protozoan diseases. The relatedness of these proteins across the different pathogens shows that there are two major phylogenetically distinct clades in the eukaryotic pathogens examined. The clustering of these proteins suggests that these transport proteins have highly conserved regions often required for basic cellular function or stability ${ }^{68-85}$. Thus, antifolate chemotherapic drugs that are effective against one pathogen might have some effect on others.

\section{Conclusion}

In summary, we have identified and classified 234 proteins after an extensive search of pathogens genome in eukaryotic pathogen resource databases, though experimental studies will be required to confirm the expression and function of these proteins in parasites. Our results show that these proteins that mediate the transportation folate are widely distributed in different pathogen species examined in various phyla. The identification of folate salvage proteins in diverse eukaryotes extend the evolutionary diversity of these proteins and suggests they might offer new possibilities for potential drug development targeting folate-salvaging routes in eukaryotic pathogens.

\section{Data availability}

Dataset 1: Complete list of proteins extracted from Eupthadb and literature search, including their properties. These data are available in a .xlsx file. Doi, 10.5256/f1000research.10561. d148742 43

Author contributions

M.O.F. and B.O. Conceptualized and Designed the study. M.O.F. and B.O. structured methodology. B.O. performed analysis. M.O.F and B.O. wrote manuscript.

\section{Competing interests}

No competing interests were disclosed.

\section{Grant information}

B.O. was supported by a TWAS-CNPq fellowship (FP number: 3240274297).

The funders had no role in study design, data collection and analysis, decision to publish, or preparation of the manuscript. 
1. Fadiel A, Isokpehi RD, Stambouli N, et al:: Protozoan parasite aquaporins. Expert Rev Proteomic. 2009; 6(2): 199-211. PubMed Abstract | Publisher Full Text

2. Prole DL, Taylor CW: Identification and analysis of putative homologues of mechanosensitive channels in pathogenic protozoa. PLoS One. 2013; 8(6): e66068.

PubMed Abstract | Publisher Full Text | Free Full Text

3. Wiser M: Protozoa and human disease. Garland Science. 2010. Reference Source

4. Turrens JF: Oxidative stress and antioxidant defenses: a target for the treatment of diseases caused by parasitic protozoa. Mol Aspects Med. 2004; 25(1-2): 211-20

PubMed Abstract | Publisher Full Text

5. Shiadeh MN, Niyyati M, Fallahi S, et al:: Human parasitic protozoan infection to infertility: a systematic review. Parasitol Res. 2016; 115(2): 469-77. PubMed Abstract | Publisher Full Text

6. Khanum H, Kadir R, Arju T, et al:: Detection of Entamoeba histolytica, Giardia lamblia and Cryptospodium sp. Infection among diarrheal patients. Bangladesh J Zoology. 2015; 43(1): 1-7.

Publisher Full Text

7. Herman ML, Surawicz CM: Intestinal Parasites. In: Textbook of Pediatric Gastroenterology, Hepatology and Nutrition. Springer International Publishing. 2016; 185-193.

Publisher Full Text

8. Ton Nu PA, Nguyen VQ, Cao NT, et al:: Prevalence of Trichomonas vaginalis infection in symptomatic and asymptomatic women in Central Vietnam. $J$ Infect Dev Ctries. 2015; 9(06): 655-60.

PubMed Abstract | Publisher Full Text

9. Garcia LS, Bruckner DA: Diagnostic medical parasitology. Washington, DC 2001; 131-5.

10. Macpherson $\mathrm{CN}$ : Human behaviour and the epidemiology of parasitic zoonoses. Int J Parasitol. 2005; 35(11-12): 1319-31.

PubMed Abstract | Publisher Full Text

11. Andrews KT, Fisher G, Skinner-Adams TS: Drug repurposing and human parasitic protozoan diseases. Int J Parasitol Drugs Drug Resis. 2014; 4(2): 95-111. PubMed Abstract | Publisher Full Text | Free Full Text

12. Ouattara A, Laurens MB: Vaccines against malaria. Clin Infect Dis. 2015; 60(6) 930-6.

PubMed Abstract | Publisher Full Text | Free Full Text

13. Monzote L, Siddiq A: Drug development to protozoan diseases. Open Med Chem J. 2011; 5(1): 1-3.

PubMed Abstract | Publisher Full Text | Free Full Text

14. Petersen I, Eastman R, Lanzer M: Drug-resistant malaria: molecular mechanisms and implications for public health. FEBS Lett. 2011; 585(11): 1551-62. PubMed Abstract | Publisher Full Text

15. Castillo E, Dea-Ayuela MA, Bolás-Fernández F, et al:: The kinetoplastid chemotherapy revisited: current drugs, recent advances and future perspectives. Curr Med Chem. 2010; 17(33): 4027-51.

PubMed Abstract | Publisher Full Text

16. Dias DA, Urban S, Roessner U: A historical overview of natural products in drug discovery. Metabolites. 2012; 2(2): 303-36.

PubMed Abstract | Publisher Full Text | Free Full Text

17. Croft SL: The current status of antiparasite chemotherapy. Parasitology. 1997 114(Suppl): S3-15.

PubMed Abstract

18. Pink R, Hudson A, Mouriès MA, et al:: Opportunities and challenges in antiparasitic drug discovery. Nat Rev Drug Discov. 2005; 4(9): 727-40. PubMed Abstract | Publisher Full Text

19. Paiardini A, Fiascarelli A, Rinaldo S, et al:: Screening and in vitro testing of antifolate inhibitors of human cytosolic serine hydroxymethyltransferase. ChemMedChem. 2015; 10(3): 490-7. PubMed Abstract | Publisher Full Text

20. Nzila A, Ward SA, Marsh K, et al:: Comparative folate metabolism in humans and malaria parasites (part I): pointers for malaria treatment from cancer chemotherapy. Trends Parasitol. 2005; 21(6): 292-8. PubMed Abstract | Publisher Full Text | Free Full Text

21. Nzila A, Ward SA, Marsh K, et al:: Comparative folate metabolism in humans and malaria parasites (part II): activities as yet untargeted or specific to Plasmodium. Trends Parasitol. 2005; 21(7): 334-9. PubMed Abstract | Publisher Full Text | Free Full Text

22. Salcedo-Sora JE, Ward SA: The folate metabolic network of Falciparum malaria. Mol Biochem Parasitol. 2013; 188(1): 51-62.

PubMed Abstract | Publisher Full Text

23. Costi MP, Ferrari S: Update on antifolate drugs targets. Curr Drug Targets. 2001 2(2): 135-66.

PubMed Abstract | Publisher Full Tex

24. Zhao R, Diop-Bove N, Visentin M, et al:: Mechanisms of membrane transport of folates into cells and across epithelia. Annu Rev Nutr. 2011; 31: 177-201. PubMed Abstract | Publisher Full Text | Free Full Text
25. Müller IB, Hyde JE: Antimalarial drugs: modes of action and mechanisms of parasite resistance. Future Microbiol. 2010; 5(12): 1857-73. PubMed Abstract | Publisher Full Text

26. Emmer BT, Nakayasu ES, Souther $\mathrm{C}$, et al:: Global analysis of protein palmitoylation in African trypanosomes. Eukaryot Cell. 2011; 10(3): 455-63.

PubMed Abstract | Publisher Full Text | Free Full Text

27. Müller IB, Hyde JE: Folate metabolism in human malaria parasites--75 years on Mol Biochem Parasitol. 2013; 188(1): 63-77.

PubMed Abstract | Publisher Full Text

28. Vickers TJ, Beverley SM: Folate metabolic pathways in Leishmania. Essays Biochem. 2011; 51: 63-80.

PubMed Abstract | Publisher Full Text | Free Full Text

29. Borst $P$, Ouellette $M$ : New mechanisms of drug resistance in parasitic protozoa. Annu Rev Microbiol. 1995; 49(1): 427-60.

PubMed Abstract | Publisher Full Text

30. Wang P, Brobey RK, Horii T, et al:: Utilization of exogenous folate in the human malaria parasite Plasmodium falciparum and its critical role in antifolate drug synergy. Mol Microbiol. 1999; 32(6): 1254-62.

PubMed Abstract | Publisher Full Text

31. Ouellette $M$, Légaré $D$, Papadopoulou $B$ : Multidrug resistance and $A B C$ transporters in parasitic protozoa. J Mol Microbiol Biotechnol. 2001; 3(2): 201-6. PubMed Abstract

32. Stein WD, Sanchez CP, Lanzer M: Virulence and drug resistance in malaria parasites. Trends Parasitol. 2009; 25(10): 441-3. PubMed Abstract | Publisher Full Text

33. Agüero F, Al-Lazikani B, Aslett M, et al:: Genomic-scale prioritization of drug targets: the TDR Targets database. Nat Rev Drug Discov. 2008; 7(11): 900-7. PubMed Abstract | Publisher Full Text | Free Full Text

34. Franzén O, Jerlström-Hultqvist J, Castro E, et al.: Draft genome sequencing of giardia intestinalis assemblage $B$ isolate GS: is human giardiasis caused by two different species? PLoS Pathog. 2009; 5(8): e1000560.

PubMed Abstract | Publisher Full Text | Free Full Text

35. Butt AM, Nasrullah I, Tahir S, et al.: Comparative genomics analysis of Mycobacterium ulcerans for the identification of putative essential genes and therapeutic candidates. PLoS One. 2012; 7(8): e43080. PubMed Abstract | Publisher Full Text | Free Full Text

36. Tiffin $N$, Adie $E$, Turner $F$, et al.: Computational disease gene identification: concert of methods prioritizes type 2 diabetes and obesity candidate genes. Nucleic Acids Res. 2006; 34(10): 3067-81. PubMed Abstract | Publisher Full Text | Free Full Text

37. Götz S, García-Gómez JM, Terol J, et al:: High-throughput functional annotation and data mining with the Blast2GO suite. Nucleic Acids Res. 2008; 36(10): 3420-35. PubMed Abstract | Publisher Full Text | Free Full Text

38. Nikolskaya T, Bugrim A, Nikolsky Y, et al:: Methods for identification of nove protein drug targets and biomarkers utilizing functional networks. United States patent US 8000949 B2; 2011.

Reference Source

39. Panwar B, Menon R, Eksi R, et al:: Genome-wide Functional Annotation of Human Protein-coding Splice Variants Using Multiple Instance Learning. J Proteome Res. 2016; 15(6): 1747-53. PubMed Abstract | Publisher Full Text

40. Antony AC: Folate receptors. Annu Rev Nutr. 1996; 16(1): 501-21. PubMed Abstract | Publisher Full Text

41. Girardin F: Membrane transporter proteins: a challenge for CNS drug development. Dialogues Clin Neurosci. 2006; 8(3): 311-21. PubMed Abstract | Free Full Text

42. Aurrecoechea $\mathrm{C}$, Heiges $\mathrm{M}$, Wang $\mathrm{H}$, et al:: ApiDB: integrated resources for the apicomplexan bioinformatics resource center. Nucleic Acids Res. 2007; 35(Database issue): D427-30.

PubMed Abstract | Publisher Full Text | Free Full Text

43. Falade M, Otarigho B: Dataset 1 in: Genome-wide characterization of folate transporter proteins of eukaryotic pathogens. F1000Research. 2017. Data Source

44. Saitou N, Nei M: The neighbor-joining method: a new method for reconstructing phylogenetic trees. Mol Biol Evol. 1987; 4(4): 406-25. PubMed Abstract

45. Sanderson MJ: Confidence limits on phylogenies: the bootstrap revisited Cladistics. 1989; 5(2): 113-29.

Publisher Full Text

46. Nei M, Kumar S: Molecular evolution and phylogenetics. Oxford university press;

Reference Source

47. Rambaut A: FigTree 1.4. 2 software. Institute of Evolutionary Biology, Univ. Edinburgh.

48. Massimine KM, Doan LT, Atreya CA, et al.: Toxoplasma gondii is capable of exogenous folate transport. A likely expansion of the BT1 family of transmembrane proteins. Mol Biochem Parasitol. 2005; 144(1): 44-54. PubMed Abstract | Publisher Full Text

49. Swaan PW: Membrane Transport Proteins and Drug Transport. Burger's 
Medicinal Chemistry and Drug Discovery. 2003. Publisher Full Text

50. Mansour TE: Chemotherapeutic targets in parasites: contemporary strategies. Cambridge University Press; 2002. Reference Source

51. Alam A, Goyal M, Iqbal MS, et al.: Novel antimalarial drug targets: hope for new antimalarial drugs. Expert Rev Clin Pharmacol. 2009; 2(5): 469-89. PubMed Abstract | Publisher Full Text

52. Dean $\mathrm{P}$, Major $\mathrm{P}$, Nakjang $\mathrm{S}$, et al:: Transport proteins of parasitic protists and their role in nutrient salvage. Front Plant Sci. 2014; 5: 153. PubMed Abstract | Publisher Full Text | Free Full Text

53. Saier MH Jr, Beatty JT, Goffeau A, et al:: The major facilitator superfamily. J Mol Microbiol Biotechnol. 1999; 1(2): 257-79. PubMed Abstract

54. Sowunmi A, Fehintola FA, Adedeji AA, et al: Open randomized study of pyrimethamine-sulphadoxine vs. pyrimethamine-sulphadoxine plus probenecid for the treatment of uncomplicated Plasmodium falciparum malaria in children. Trop Med Int Health. 2004; 9(5): 606-14. PubMed Abstract | Publisher Full Text

55. Nzila A, Mberu E, Bray $\mathrm{P}$, et al.: Chemosensitization of Plasmodium falciparum by probenecid in vitro. Antimicrob Agents Chemother. 2003; 47(7): 2108-12. PubMed Abstract | Publisher Full Text | Free Full Text

56. Richard D, Kündig $C$, Ouellette $M$ : A new type of high affinity folic acid transporter in the protozoan parasite Leishmania and deletion of its gene in methotrexate-resistant cells. J Biol Chem. 2002; 277(33): 29460-7. PubMed Abstract | Publisher Full Text

57. Richard D, Leprohon P, Drummelsmith J, et al: Growth phase regulation of the main folate transporter of Leishmania infantum and its role in methotrexate resistance. J Biol Chem. 2004; 279(52): 54494-501. PubMed Abstract | Publisher Full Text

58. Kündig C, Haimeur A, Légaré D, et al.: Increased transport of pteridines compensates for mutations in the high affinity folate transporter and contributes to methotrexate resistance in the protozoan parasite Leishmania tarentolae. EMBO J. 1999; 18(9): 2342-51.

PubMed Abstract | Publisher Full Text | Free Full Text

59. Gottesdiener KM: A new VSG expression site-associated gene (ESAG) in the promoter region of Trypanosoma brucei encodes a protein with 10 potential transmembrane domains. Mol Biochem Parasitol. 1994; 63(1): 143-51. PubMed Abstract | Publisher Full Text

60. Stewart RA, Meyer KF: Isolation of Coccidioides immitis (Stiles) from the soil. Exp Biol Med. 1932; 29(8): 937-8. Publisher Full Text

61. Greene DR, Koenig G, Fisher MC, et al:: Soil isolation and molecular identification of Coccidioides immitis. Mycologia. 2000; 92(3): 406-10.

Publisher Full Text

62. Litvintseva AP, Marsden-Haug N, Hurst S, et al:: Valley fever: finding new places for an old disease: Coccidioides immitis found in Washington State soil associated with recent human infection. Clin Infect Dis. 2015; 60(1): e1-3. PubMed Abstract | Publisher Full Text | Free Full Text

63. Hajji M, Kanoun S, Nasri M, et al:: Purification and characterization of an alkaline serine-protease produced by a new isolated Aspergillus clavatus ES1. Process Biochem. 2007; 42(5): 791-7.

Publisher Full Text

64. Rodríguez-Cerdeira C, Arenas R, Moreno-Coutiño G, et al:: Systemic fungal infections in patients with human inmunodeficiency virus. Actas Dermosifiliog. 2014; 105(1): 5-17.

PubMed Abstract | Publisher Full Text

65. Awadelkariem FM, Hunter KJ, Kirby GC, et al.: Crithidia fasciculata as feeder cells for malaria parasites. Exp Parasitol. 1995; 80(1): 98-106. PubMed Abstract | Publisher Full Text

66. Krungkrai J, Cerami A, Henderson GB: Pyrimidine biosynthesis in parasitic protozoa: purification of a monofunctional dihydroorotase from Plasmodium berghei and Crithidia fasciculata. Biochemistry. 1990; 29(26): 6270-5. PubMed Abstract | Publisher Full Text

67. Eyal E, Najmanovich R, Mcconkey BJ, et al.: Importance of solvent accessibility and contact surfaces in modeling side-chain conformations in proteins. $J$ Comput Chem. 2004; 25(5): 712-24.

PubMed Abstract | Publisher Full Text
68. Fedorova ND, Khaldi N, Joardar VS, et al:: Genomic islands in the pathogenic filamentous fungus Aspergillus fumigatus. PLoS Genet. 2008; 4(4): e1000046. PubMed Abstract | Publisher Full Text | Free Full Text

69. Nierman WC, Yu J, Fedorova-Abrams ND, et al:: Genome sequence of Aspergillus flavus NRRL 3357, a strain that causes aflatoxin contamination of food and feed. Genome Announc. 2015; 3(2): e00168-15. PubMed Abstract | Publisher Full Text | Free Full Text

70. Katinka MD, Duprat S, Cornillot E, et al.: Genome sequence and gene compaction of the eukaryote parasite Encephalitozoon cuniculi. Nature. 2001; 414(6862): 450-3.

PubMed Abstract | Publisher Full Text

71. Rogers MB, Hilley JD, Dickens NJ, et al: Chromosome and gene copy number variation allow major structural change between species and strains of Leishmania. Genome Res. 2011; 21(12): 2129-42. PubMed Abstract | Publisher Full Text | Free Full Text

72. Selman M, Sak B, Kváč M, et al.: Extremely reduced levels of heterozygosity in the vertebrate pathogen Encephalitozoon cuniculi. Eukaryot Cell. 2013; 12(4): 496-502.

PubMed Abstract | Publisher Full Text | Free Full Text

73. Kaur K, Coons T, Emmett K, et al:: Methotrexate-resistant Leishmania donovan genetically deficient in the folate-methotrexate transporter. J Biol Chem. 1988; 263(15): 7020-8. PubMed Abstract

74. Beck JT, Ullman B: Affinity labeling of the folate-methotrexate transporter from Leishmania donovani. Biochemistry. 1989; 28(17): 6931-7. PubMed Abstract | Publisher Full Text

75. Richard D, Leprohon P, Drummelsmith J, et al:: Growth phase regulation of the main folate transporter of Leishmania infantum and its role in methotrexate resistance. J Biol Chem. 2004; 279(52): 54494-501. PubMed Abstract | Publisher Full Text

76. Ouameur AA, Girard I, Légaré D, et al:: Functional analysis and complex gene rearrangements of the folate/biopterin transporter (FBT) gene family in the protozoan parasite Leishmania. Mol Biochem Parasitol. 2008; 162(2): 155-64. PubMed Abstract | Publisher Full Text

77. Ubeda JM, Légaré $\mathrm{D}$, Raymond $\mathrm{F}$, et al.: Modulation of gene expression in drug resistant Leishmania is associated with gene amplification, gene deletion and chromosome aneuploidy. Genome Biol. 2008; 9(7): R115. PubMed Abstract | Publisher Full Text | Free Full Text

78. Flegontov P, Butenko A, Firsov S, et al:: Genome of Leptomonas pyrrhocoris: a high-quality reference for monoxenous trypanosomatids and new insights into evolution of Leishmania. Sci Rep. 2016; 6: 23704. PubMed Abstract | Publisher Full Text | Free Full Text

79. Kraeva N, Butenko A, Hlaváčová J, et al:: Leptomonas seymouri: Adaptations to the Dixenous Life Cycle Analyzed by Genome Sequencing, Transcriptome Profiling and Co-infection with Leishmania donovani. PLoS Pathog. 2015; 11(8): e1005127.

PubMed Abstract | Publisher Full Text | Free Full Text

80. El-Sayed NM, Myler PJ, Blandin G, et al.: Comparative genomics of trypanosomatid parasitic protozoa. Science. 2005; 309(5733): 404-9. PubMed Abstract | Publisher Full Text

81. El-Sayed NM, Myler PJ, Bartholomeu DC, et al:: The genome sequence of Trypanosoma cruzi, etiologic agent of Chagas disease. Science. 2005; 309(5733): 409-15.

PubMed Abstract | Publisher Full Text

82. Massimine KM, Doan LT, Atreya CA, et al.: Toxoplasma gondii is capable of exogenous folate transport. A likely expansion of the BT1 family of transmembrane proteins. Mol Biochem Parasitol. 2005; 144(1): 44-54. PubMed Abstract | Publisher Full Text

83. Kelly S, Ivens A, Manna PT, et al:: A draft genome for the African crocodilian trypanosome Trypanosoma grayi. Sci Data. 2014; 1: 140024. PubMed Abstract | Publisher Full Text | Free Full Text

84. Stoco PH, Wagner G, Talavera-Lopez C, et al:: Genome of the avirulent humaninfective trypanosome--Trypanosoma rangeli. PLOS Neg/ Trop Dis. 2014; 8(9): e3176.

PubMed Abstract | Publisher Full Text | Free Full Text

85. Kumar S, Stecher G, Tamura K: MEGA7: Molecular Evolutionary Genetics Analysis Version 7.0 for Bigger Datasets. Mol Biol Evol. 2016; 33(7): 1870-4. PubMed Abstract | Publisher Full Text 


\section{Open Peer Review}

\section{Current Peer Review Status: ? ?}

\section{Version 1}

Reviewer Report 06 March 2017

https://doi.org/10.5256/f1000research.11380.r20419

(C) 2017 Singh G. This is an open access peer review report distributed under the terms of the Creative Commons Attribution License, which permits unrestricted use, distribution, and reproduction in any medium, provided the original work is properly cited.

\section{Gajinder Singh}

Molecular Medicine Group, International Centre for Genetic Engineering and Biotechnology (ICGEB), New Delhi, Delhi, India

Below are my major concerns:

1. The abstract does not provides an adequate summary of the article.

The authors have claimed much higher scope of their work than actually reported. While their work is restricted to folate transporters, they have claimed to work on whole folate pathway. In the Abstract: "We applied a combination of bioinformatics methods to examine the genomes of pathogens in the EupathDB for genes encoding homologues of proteins that mediate folate salvage in a bid to identify and assign putative functions." "These findings offer new possibilities for potential drugConclusion: development targeting folatesalvage proteins."

2. No proper justification for the work is provided.

a) While folate pathway is well established as drug target, the authors have only identified folate transporters. So please give examples of drugs (with names) which are known to target folate transporters in any organism. If no sufficient information is provided, the usefulness of the work is severely reduced.

b) How many of folate transporters are essential in species where essentiality data is available such as P. berghei and T. gondii?

3. The methodology to identify transporters is not comprehensive.

Since authors have used key-word searches to identify folate transporters, they are likely to miss many transporters not labelled as such. An appropriate methodology will incorporate profile (such as HMM) based searches. Thus the number of transporters identified by authors is most likely to be an underestimate. 


\section{The methodology is not clear.}

Authors write that "we utilized the word "folate" for search on the gene text and "folic acid" was used to confirm the hits", then how only transporters were retrieved?

The Figure 1 is confusing. Where is BLAST used here?

5. The manuscript is written very poorly with so many scientific and grammatical mistakes that it is very difficult for the reader to follow the manuscript. Below are some examples.

a) "The mitochondrion is the predicted location of the majority of the proteins, with $15 \%$ possessing signal peptides." - how can mitochondria be majority location if only $15 \%$ have signal peptides and even less with mitochondrial signal peptide? Shouldn't the majority then be cytoplasmic?

b) "We identified 234 proteins to be involve in folate transport".

c) "Since folate-binding protein YgfZ, folate/ pteridine transporter, folate/biopterin transporter, putative, reduced folate carrier family protein, folate/methotrexate transporter FT1, putative folate transporters alone and others have 10, 25, 132, 2, 7, 49 and 9." What are these numbers?

d) "So we decided to reconstruct the phylogeny based folate transporter, folate-biopterin transporter after considering the identification number, the species diversity in each category."

e) "The different proteins identified to be involved in folate salvage or related molecules were folatebinding protein $\mathrm{YgfZ}$, folate/pteridine transporter, folate/biopterin transporter, reduced folate carrier family protein, folate/methotrexate transporter FT1 and folate transporters having a $4 \%, 11 \%, 56 \%, 1 \%, 3 \%$ and $21 \%$ identity, respectively." What does this statement mean?

f) Does Table 1 really need to be 4 page long?

g) "The only Plasmodium species with results for proteins that salvage folate was $P$. falciparum"

h) "However, folate transporters I and II were retrieved from our search of GeneDB for P. malariae and P. ovale curtisi, respectively." What are these transporter classes?

i) "Some of these pathogens include P. ultimum DAOM BR144, which has mitochondrial folate transporter/carrier proteins similar to Homo sapiens, E. cuniculi GB-M1, which has proteins similar to folate transporter, and S. punctatus DAOM BR117, which has folatebinding protein YgfZ."

j) "After phylogenetic analysis each sub-phylogeny show a clear characterization except for folate-biopterin transporters" 
h) "In this study, 234 genes encoding homologues of folate salvaging proteins were identified in the genome of 64 strains, representing 28 species of eukaryotic pathogens. Some of the pathogens include P. falciparum 3D7 and IT, P. knowlesi H, P. berghei ANKA, P. chabaudi chabaudi, T. brucei Lister 427, T. brucei TREU927, T. brucei gambiense DAL972, Encephalitozoon cuniculi GB-M1. The pathogens range from bacteria through to fungi, intracellular parasites such as Plasmodium and leishmania species, to extracellular parasites such as trypanosome species" Which bacteria was included in the study?

i) "It has been estimated that over half of the drugs currently on the market target integral membrane proteins of which membrane transporters are a part, but unfortunately, these transporters have not been adequately explored as drug targets. Folate transporters therefore represent attractive drug targets for treatment of infectious diseases." Please tell us how many drugs are available in the market which target folate transporters, which is a more relavant statistic with respect to this study.

j) "In the trypanosomes and related kinetoplastids, a member of these transporters, the folate biopterin transporter (FBT) family of proteins was identified in Leishmania."

k) "It is thought that MFS proteins are related to the FBT." What is MFS?

I) "Results from our study describing the presence of these transporters across several phyla corroborate results other researches, establishing the conservation of folate transport function among FBT family proteins from species from plants and protists".

m) "The clustering of these proteins suggests that these transport proteins have highly conserved regions often required for basic cellular function or stability". The clustering does not suggest that these transport proteins have highly conserved regions often required for basic cellular function or stability.

n) " We also performed phylogenetic comparisons of identified proteins. .".

Competing Interests: No competing interests were disclosed.

I confirm that I have read this submission and believe that I have an appropriate level of expertise to confirm that it is of an acceptable scientific standard, however I have significant reservations, as outlined above.

Reviewer Report 27 February 2017

https://doi.org/10.5256/f1000research.11380.r20535

(C) 2017 Isokpehi R. This is an open access peer review report distributed under the terms of the Creative Commons Attribution License, which permits unrestricted use, distribution, and reproduction in any medium, provided the original work is properly cited.

\section{Raphael D. Isokpehi}


College of Science, Engineering and Mathematics (CSEM) , Bethune-Cookman University , Daytona Beach, FL, USA

\section{Summary of Referee's Report}

The manuscript presents a strong justification for research on folate transporter proteins as drug targets for diseases caused by eukaryotic pathogens including the malaria parasite. The manuscript reports a data curation effort that involves the use of the Eukaryotic Pathogens Database (EuPathDB) Resource. Several novel results to guide future research are included such as (i) a list of 234 folate transporter proteins from 63 eukaryotic microbes including eukaryotic pathogens; and (ii) phylogenetic trees of relatedness of the protein sequences. The authors observed the clustering of the protein sequences that indicate the possibility that antifolate drugs could be effective for multiple eukaryotic pathogens.

Major concerns are:

(i) The need for a clearer description of the workflow for the construction of the protein list.

(ii) There is inadequate support for the statement that " $60 \%$ of the proteins were identified for the first time".

(iii) Confusion between retrieval and identification of protein sequences. The workflow diagram indicates retrieval of sequences but narrative text describes identification in multiple sections. The potential drug targeting categorization of the retrieved protein sequences is a key contribution of the research study.

Some minor concerns include (i) typographic errors such as spelling of abbreviations (e.g. EuPathDB, PubMed and UniProt); (ii) classification of A. (Ajellomyces) capsulatus G186AR as a bacteria; and (iii) need to quantify the statistics associated with observations (Examples: in abstract "Many of the genomes"; in discussion: "A few of the proteins" ).

Title and Abstract:

\section{Is the title appropriate for the content of the article?}

The manuscript title is "Genome-wide characterization of folate transporter proteins of eukaryotic pathogens". "Genome-wide characterization" does not effectively describe the accomplishments of the research reported. The manuscript in the conclusion section (Page 15) states "we have identified and classified 234 proteins...". The workflow (Figure 1) provides categorization of proteins by features such as cellular location, presence of signal peptide and number of transmembrane helices. Figure 2 has the title "Categorization of proteins identified". A suggested revised title is "Categorization of potential drug targeting folate transporter proteins from eukaryotic pathogens". The "potential drug targeting" is obtained from the conclusion section.

\section{Does the abstract represent a suitable summary of the work?}

There are sentences in the abstract that should be revised to accurately represent a suitable summary of the research performed. Comments/suggestions are provided below.

1. Quantify the observations described as many. For example "genome sequences of many": How many?

2. "eukaryotic protozoa" > "eukaryotic microbes". The term "eukaryotic microbes" encompasses pathogens and non-pathogens (e.g. Chromera velia and Vitrella brassicaformis ) . 
3. "important data" > "critical biological information"

4. "pathway are important for" > "pathways are necessary for"

5. "Methods: We applied a combination of bioinformatics methods to examine the genomes of pathogens in the EupathDB for genes encoding homologues of proteins that mediate folate salvage in a bid to identify and assign putative functions." > "Methods: We developed automated search strategies in the Eukaryotic Pathogen Database Resources (EuPathDB) to construct a protein list and retrieve protein sequences of folate transporters encoded in the genomes of 200 eukaryotic microbes. The folate transporters were categorized according to features including mitochondrial localization, number of transmembrane helix, and protein sequence relatedness.

6. Provide key result(s) of the protein list retrieval and phylogenetic comparison of the retrieved proteins. For example, We constructed a list of 234 folate transporter proteins associated with 63 eukaryotic microbes including ??? algae, ??? fungi and ??? protozoa. Seven percent of the proteins were predicted to localize on the mitochondrial membrane. Phylogenetic tree revealed major (??? proteins) and minor (??? Proteins) clades. All the folate transporter sequences from the malaria parasite, Plasmodium, belonged to the major clade.

7. "The mitochondrion is the predicted location of the majority of the proteins". This statement is not supported by Figure 2D, where $7 \%$ of the protein sequences are labelled as Mitochondrial folate transporters.

\section{Article content:}

Have the design, methods and analysis of the results from the study been explained and are they appropriate for the topic being studied?

\section{Design and Methods:}

1. Figure 1 presents a conceptual hierarchical methodology. The rectangle labelled "Protein names/ sequences verification" has arrows to PubMed, UniProt, Membranetransporters.org, NCBI, GeneDB, Google Scholar and Phylogenetic analyses. It appears that the integrated results from the search strategies in the databases provided the input for the phylogenetic analyses. Please clarify.

2. Which step of the workflow resulted in the list of 234 proteins?

3. How many proteins were retrieved from the initial search using EuPathDB?

4. Protein Features Retrieved rectangle: Was the retrieval of protein features performed on only the 234 proteins?

5. There is adequate explanation of the methods for phylogenetic analyses. Please provide the Newick format phylogenetic tree as a supplementary dataset.

\section{Analysis of the Results:}

1. Table 1 is a major curation effort presented in the manuscript.

a. The title of Table 1 should be updated to "Eukaryotic microbes from which folate 
transporters were identified". The list includes non-pathogens.

b. The content of the table (especially the Kingdom entries) should be checked for accuracy. The Kingdom column could be updated to Eukaryotic Microbe Group with entries as algae, protozoa or fungi.

c. The column entries for A. capsulatus G186AR (mislabelled as bacteria) should be updated as the organism name is for a fungus (genus Ajellomyces). This update will also affect the Phylogenetic Tree (Figure 3). The node labelled Actinobacillus clusters with Ajellomyces macrogynus.

d. An updated Table 1 should be presented as Dataset 2 in a spreadsheet file. This would enable secondary data analysis by other researchers.

e. A new Table 1 could consist of columns for Eukaryotic Microbe Group, Genera of Eukaryotic Microbe, List of Species/Strain and Number of Folate Transport Proteins. This will provide reader with an overview of how the 234 proteins is distributed into the genera of the eukaryotic microbes.

f. References listed for confirmation searches. Page 8, Paragraph 1, Sentence 1: “Our literature search for parasite folate transporters on PubMed and Google Scholar indicated $60 \%$ (38 out 63) of the proteins were identified for the first time as presented in Table 1. Comment: Among the references included in Table 1, only eight references (22, 73 to 77 and 82) on the basis of the article title provide experimental assessments of the folate transporters. Reference 85 is a reference for MEGA7 software. In the sentence "proteins" should be eukaryotic microbes. The proportion of eukaryotic microbes whose folate transporter(s) have been previously investigated with functional assays should be revised.

2. Figure 2. Categorization of proteins identified.

Authors should consider representing Figure $2 \mathrm{~A}$ and $2 \mathrm{~B}$ as bar graphs. Figures $2 \mathrm{C}, 2 \mathrm{D}$ and $2 \mathrm{E}$ have only two categories that can be described in the Results section.

\section{Discussion}

a. "genomes of 64 strains". Table 1 has 63 eukaryotic microbes.

b. Discuss Chromera velia and Vitrella brassicaformis as organismal systems for investigating folate transporter function. See Woo et al. ${ }^{1}$

4. Conclusion

Consider revising "In summary, we have identified and classified 234 proteins..." to "In summary, we have retrieved information on 234 folate transporter proteins from the Eukaryotic Pathogen Database (EuPathDB) resources. The folate transporter proteins were categorized into potential drug targeting features including mitochondrial localization, number of transmembrane helix, and protein sequence relatedness."

Data (if applicable):

Has enough information been provided to be able to replicate the experiment? Are the data in a usable format/structure and have all the data been provided?

1. Table 1 needs to be revised and converted to a Dataset.

2. Please provide the Newick format phylogenetic tree as a supplementary dataset.

3. The Gene Identifiers [Gene ID] in Dataset 1 can be used to retrieve the protein sequences from EuPathDB. 


\section{References}

1. Woo $\mathrm{YH}$, Ansari $\mathrm{H}$, Otto TD, Klinger CM, et al.: Chromerid genomes reveal the evolutionary path from photosynthetic algae to obligate intracellular parasites.Elife. 2015; 4: e06974 PubMed Abstract | Publisher Full Text

Competing Interests: No competing interests were disclosed.

I confirm that I have read this submission and believe that I have an appropriate level of expertise to confirm that it is of an acceptable scientific standard, however I have significant reservations, as outlined above.

The benefits of publishing with F1000Research:

- Your article is published within days, with no editorial bias

- You can publish traditional articles, null/negative results, case reports, data notes and more

- The peer review process is transparent and collaborative

- Your article is indexed in PubMed after passing peer review

- Dedicated customer support at every stage

For pre-submission enquiries, contact research@f1000.com 